\title{
A history of hubris - Cautionary lessons in ecologically sustainable forest management
}

\author{
David B. Lindenmayer ${ }^{\mathrm{a}, *}$, William F. Laurance ${ }^{\mathrm{b}, 1}$ \\ ${ }^{a}$ Fenner School of Environment and Society, The Australian National University, Canberra, ACT 0200, Australia \\ ${ }^{\mathrm{b}}$ Centre for Tropical Environmental and Sustainability Science (TESS) and School of Marine and Tropical Biology, James Cook University, Cairns, Qld 4878, Australia
}

\section{A R T I C L E I N F O}

\section{Article history:}

Received 25 August 2011

Received in revised form 26 October 2011

Accepted 31 October 2011

Available online 9 January 2012

\section{Keywords:}

Ecosystem services

Forest management

Logging practices

Native forests

Sustainable harvests

Wildlife conservation

\begin{abstract}
A B S T R A C T
Logging is one of the most important forms of native-forest exploitation and can have substantial impacts on biodiversity and key ecosystem services. Here we briefly contrast logging operations in temperate and tropical forests and then highlight several challenges for understanding the ecological impacts of logging. We argue that many logging studies are conducted at small spatial scales or over inadequate time periods, and are biased against finding significant negative impacts. This is because of confounding environmental differences between logged and unlogged forests as well as the prolonged nature of forest stand development. Human perceptions of logging also can be biased by the 'shifting baseline' phenomenon, and by an incorrect perception that logging operations approximate natural disturbance regimes. We argue that the ecological impacts of logging can be more challenging to detect than is often appreciated, and that forest managers and decision-makers should be cautious when weighing the arguments of prologging lobbies.
\end{abstract}

\section{Contents}

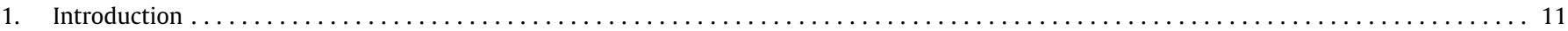

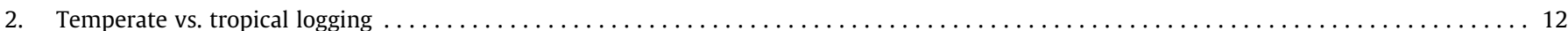

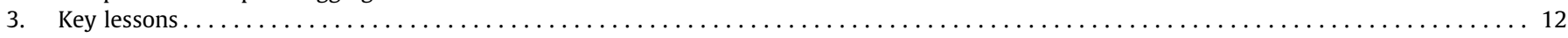

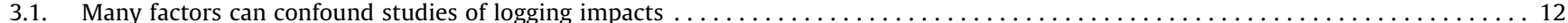

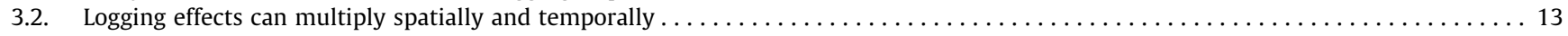

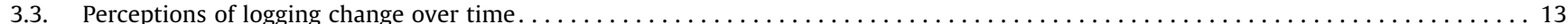

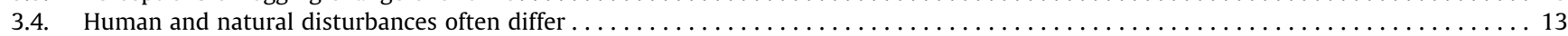

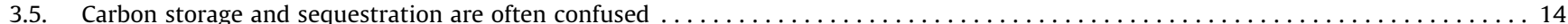

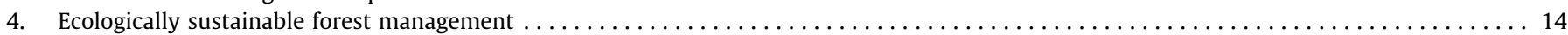

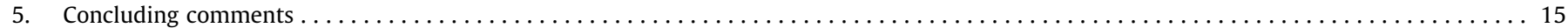

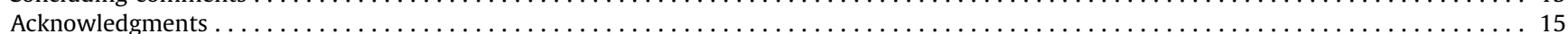

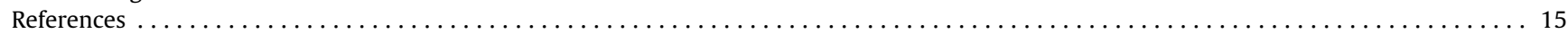

\section{Introduction}

Around the world, forest management for timber production has long been one of the most controversial, and sometimes divisive, natural resource issues (e.g. Yaffee, 1994; Puettmann et al., 2008). Many debates have arisen over the impacts of timber

\footnotetext{
* Corresponding author. Tel.: +612 61250654; fax: +61261250757.

E-mail addresses: david.lindenmayer@anu.edu.au (D.B. Lindenmayer), bill. laurance@jcu.edu.au (W.F. Laurance).

1 Tel.: +61 7 40421819; fax: +61740421319.
}

harvesting on other forest values, particularly the conservation of biodiversity (Lindenmayer and Franklin, 2002; Gibson et al., 2011) (for instance, see the contrasting views of Paillet et al. (2009) vs. Halme et al. (2010)).

Here we briefly examine several aspects of the debate over logging impacts on biodiversity, based on our combined 60 years of experience in working in temperate forests (e.g. Lindenmayer et al., 1999, 2009; Lindenmayer, 2009) and tropical forests (e.g. Laurance, 1991; Laurance et al., 1997, 2000, 2007). This exercise is important, we believe, because aspects of these recurring arguments are either flawed or often misunderstood, meaning that 


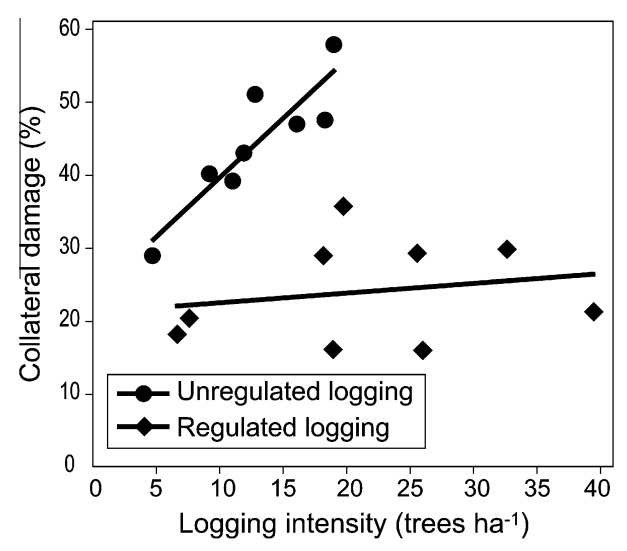

Fig. 1. Reduced-impact logging methods can markedly reduce forest damage. Shown are data from different logging studies in Southeast Asia (unregulated logging) and north Queensland (regulated logging). Collateral damage is the percentage of non-harvested trees $(\geqslant 10 \mathrm{~cm}$ diameter) that were killed during logging operations (data from Crome et al., 1992).

forest managers and decision-makers should be cautious when weighing the arguments of pro-logging lobbies or interpreting logging-impact research.

\section{Temperate vs. tropical logging}

At the outset, it is important to emphasize that logging typically differs between temperate and tropical regions. Forest stands in temperate regions are often dominated by a small number of tree species, and in many cases stands are clearcut in a mosaic pattern (Puettmann et al., 2008). In some harvesting operations, living and dead trees that provide hollows for wildlife as well as strips of vegetation along watercourses are retained (e.g. Carey, 2007; Bunnell and Dunsworth, 2009). Logging of temperate and boreal moist forests can make them more fire prone (Odion et al., 2004; Thompson et al., 2007; Lindenmayer et al., 2009) and this may even result in regime shifts as a result of significant alterations in fire frequency and/or severity (Lindenmayer et al., 2011a).

In the tropics, tree species richness is far higher than in temperate forests and only a limited number of larger trees are harvested - typically from 1-20 trees per hectare (Crome et al., 1992; Felton et al., 2008). Unharvested species are generally those that have undesirable wood properties, are too small, or are too rare or poorly known to be exploited by wood-products industries. Although cutting is selective, logging operations in the tropics can cause a substantial (10-80\%) loss of forest canopy-cover and

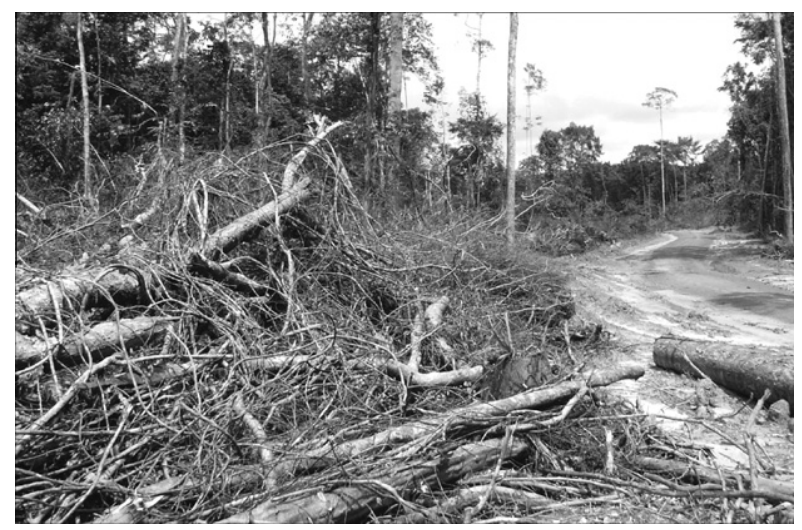

Fig. 2. Logging operations often create large amounts of dry, fine fuels that can promote forest fires, as shown here in the Congo Basin (photo by W.F. Laurance). heavy collateral mortality of non-harvested trees (Fimbel et al., 2001). As we discuss further below, such damage can be considerably diminished via reduced-impact logging methods (Putz et al., 2008) (Fig. 1).

In a separate paper in this issue, highlight many challenges involved in the sustainable logging of native forests in the tropics. For tropical wildlife, impacts on populations can arise not only from the logging operation itself but also from important secondary effects. In particular, forest roads created by logging operations tend to facilitate a sharp increase in hunting, slash-and-burn farming and human colonization of forests (Redford, 1992; Laurance, 2001; Asner et al., 2006), whereas the dry, fine debris created by logging operations (Fig. 2) in concert with increased human ignition sources can lead to a major increase in destructive wildfires (Uhl and Kauffman, 1990; Malhi et al., 2009). Fires can be particularly harmful to tropical rainforests because few plant species are adapted to survive even low-intensity fires (Cochrane, 2003; Cochrane and Laurance, 2008).

\section{Key lessons}

\subsection{Many factors can confound studies of logging impacts}

Numerous studies have sought to assess the effects of logging on biodiversity by contrasting the biota of logged and unlogged sites (see reviews by Lindenmayer and Franklin, 2002; Paillet et al., 2009). Non-significant results are sometimes interpreted as a lack of impact or only benign effects of logging on biodiversity and ecosystem processes. However, robust logging-impact studies are far from straightforward for a range of reasons, including the three considered briefly below.

First, site productivity can confound comparisons of logged and unlogged sites (Chazdon et al., 2009; Gardner et al., 2009) (see Kavanagh and Bamkin (1995) for an example of this). Logging is often concentrated in flatter, lower-elevation areas that tend to occur on richer alluvial or basaltic soils, whereas unlogged sites are often in steep, rocky, higher-elevation sites that generally have lower soil fertility and forest productivity. Such differences can substantially influence the structure, floristic composition, and faunal communities of sites independently of logging, and may reduce the likelihood of finding significant logging impacts on disturbance-sensitive fauna because they are naturally more abundant in the more productive, lower-elevation sites (Huggett and Cheeseman, 2002; Lindenmayer and Franklin, 2002).

Second, detecting long-term impacts of logging on biodiversity can be extremely difficult because forest trees can be very longlived (Chambers et al., 1998; Laurance et al., 2004) and forest-stand development can span centuries (Johnson and Miyanishi, 2008). Many investigations have substituted space for time in an attempt to overcome this (Lindenmayer and Likens, 2010). However, such retrospective studies can fail to account for the important influence of site history on biodiversity (Gustavsson et al., 2007), sometimes leading to erroneous conclusions (Pickett, 1989; Lindenmayer et al., 2011b).

Finally, some of the most significant impacts of logging on biodiversity are cumulative over space (Lindenmayer et al., 2011a), over time, or both. For example, logging - especially low-intensity selective logging or shelterwood-silvicultural systems - can have relatively limited effects after a single cutting cycle (Grieser Johns and Grieser Johns, 1995; Greiser Johns, 1997). However, repeated cutting events can substantially alter stand structure (Kellas and Hateley, 1991; Linder and Östlund, 1998), leading to significant negative effects on particular elements of the biota (Lindenmayer and Franklin, 2002). Cumulative effects on forest biodiversity can be extremely difficult to quantify (Cocklin et al., 1992) (but see 
Edwards et al., 2010) and may require the integration of a range of data from studies of a range of taxa including "non-charismatic" groups such invertebrates (e.g. Barlow et al. 2007; Gardner et al., 2009), coupled with the collective insights of observational studies, landscape analyses, monitoring programs and simulation modeling (Spies et al., 2007; Lindenmayer, 2009).

In summary, it is almost impossible to conduct a "perfect" study to fully quantify logging effects on forest biodiversity. Even true experiments (e.g. Crome et al., 1992; Yabe et al., 1998) and natural experiments can be problematic; for example, they are typically conducted at a small spatial scale that necessarily limits inferences about wide-ranging species. Therefore, we suggest that researchers and resource managers need to be aware of the limitations of work contrasting the biodiversity of logged and unlogged areas. There is also a need to carefully design logging studies to minimize key problems like the potential for confounding between environmental conditions and logging (Chazdon et al., 2009; Gardner et al., 2009); for example, through the use of a randomized block design. In addition, logging studies need to untangle the impacts of direct effects that result from cutting down trees from the indirect effects that can accompany logging, such as increased hunting pressure. Finally, given these potential problems with logging studies, we suggest that conservation biologists, forest ecologists and forest managers should be circumspect in interpreting the results of such investigations and therefore be very conservative in designing prescriptions for biodiversity conservation within timber-production landscapes.

\subsection{Logging effects can multiply spatially and temporally}

An argument frequently advanced to suggest logging has benign effects on biodiversity and ecosystem processes is that only a small fraction of a given forest region is logged in any given year. This argument is often advanced by government agencies, pro-logging politicians and lobby groups (e.g. World Growth, 2010; Department of Primary Industries - New South Wales, 2011; Victorian Association of Forest Industries, 2011). However, this argument overlooks several key issues.

First, there can be a potential for cumulative spatial effects of many cut-blocks across a landscape. The impact of a single cutblock in a forest landscape might be limited, but substantial effects may arise when many areas are harvested over a full rotation (Franklin and Forman, 1987). For example, the loss of structural complexity within stands can accumulate over many cutover sites and result in a highly homogenized landscape.

Second, logging operations often occur in the most productive parts of landscapes (Chazdon et al., 2009; Gardner et al., 2009), which are important for many elements of the biota (see above). Such landscape-scale changes can influence disturbance-sensitive species that can be effectively conserved only within large ecological reserves that are exempt from timber production (e.g. Lindenmayer et al., 1999; Peres, 2005).

Third, logging may fundamentally alter key ecological processes like fire regimes and make forests more fire-prone and subject to more frequent, more severe and more spatially extensive wildfires (Uhl and Kauffman, 1990; Thompson et al., 2007; Lindenmayer et al., 2011a). Thus, the impacts of logging-related or logging-promoted fires can extend far beyond the direct area subject to logging, with subsequent affects on biodiversity, carbon storage and ecosystem functions.

Finally, suggestions that logging is benign because it affects only a small fraction of the forest in any given year are often made in the absence of ecological context. That is, logging impacts need to be considered in the context of prior disturbances, such as earlier logging, fires or windstorms and should also consider which parts of the forest are being targeted for harvesting (e.g. areas of high conservation value or that are critical for particular species or ecological processes). For example, even a limited amount of logging in a given year can have significant negative ecological effects if much of the original natural cover of forest has already been logged or extensively naturally disturbed.

In summary, while in some landscapes only a comparatively small area of forest is logged in any given year, we argue that it is essential for conservation biologists and forest managers to consider the potential for (1) cumulative spatial effects of many logged areas within wood-production landscapes (Franklin and Forman, 1987); (2) cumulative temporal effects from multiple harvesting cycles within any given stand (Kellas and Hateley, 1991; Linder and Östlund, 1998); (3) problems for biodiversity arising from logging operations being concentrated in the most productive parts of landscapes, and (4) the potential for large-scale changes in ecological processes, such as fire regimes, that can occur throughout forested landscapes as a result of logging operations (Uhl and Kauffman, 1990; Lindenmayer et al., 2011a).

\subsection{Perceptions of logging change over time}

Management practices deployed over substantial periods can greatly modify environmental conditions (Linder and Östlund, 1998) that in turn strongly influence both biodiversity and human perceptions of what is 'natural' in a region (Milly et al., 2008). This is the concept of 'shifting baselines' (Papworth et al., 2009), common in studies of marine ecosystems (Pauly, 1995; Baum and Myers, 2004) but also highly relevant in forest environments (Angelstam et al., 1995). For example, the forests of Scandinavia have been extensively modified over the past three centuries (Linder and Östlund, 1998; Gustafsson et al., 2010) and, as a result, many forest managers there find it difficult to believe that unmanaged forests naturally have abundant deciduous trees and wood debris (Angelstam et al., 1995). Similarly, in the wet forests of south-eastern Australia, recurrent logging, frequent high-intensity wildfires, and post-fire salvage logging have led to widespread even-aged regrowth stands (Department of Sustainability and Environment, VicForests, 2008). Forest managers failed to recognize that multi-age stands were once widespread, in part because evidence of them had largely vanished from wood-production zones (Lindenmayer, 2009). The widespread extirpation of large predators from many tropical and temperate forests (Corlett, 2007; Ritchie and Johnson, 2009) also can create pervasive ecological distortions - such as hyper-abundant herbivores or generalist omnivores - that eventually come to be considered 'natural'.

Given the potential for significant shifts in forest condition as a result of prolonged human disturbance, we suggest it is important for resource managers to explicitly recognize the risks of shifting baselines given the potentially potent influences of past management practices on biodiversity. This is particularly important for guiding attempts to create management practices that mimic natural disturbance regimes (Hunter, 2007; see below) and for restoring sensitive wildlife to managed forests (e.g. Soulé and Noss, 1998; Roccaforte et al., 2010).

\subsection{Human and natural disturbances often differ}

Natural disturbances shape many aspects of forest composition and structure at the tree, stand, ecosystem and landscape scales (Frelich, 2005). Most natural disturbances leave traces and features of the original stand in the form of biological legacies. Biological legacies are organisms, organically-derived structures, and organically-produced patterns that persist from the pre-disturbance ecosystem (Franklin et al., 2000) and they include logs, intact thickets of understory vegetation, large living trees, and snags (Lindenmayer and Franklin, 2002). Organisms are likely to be best adapted 
to the disturbance regimes under which they have evolved, and many authors (reviewed by Hunter, 2007) have advocated forest management strategies that attempt to mimic natural disturbance to conserve biodiversity (Hunter, 1993; Korpilahti and Kuuluvainen, 2002).

However, the concept of using natural disturbance regimes to guide human disturbance regimes has sometimes been abused. It has been invoked, for instance, to justify clearcutting in forests subject to rare, high-severity wildfires, such as the wet eucalypt forests of south-eastern Australia. This is because clearcutting and wildfire were considered "ecologically equivalent" (National Association of Forest Industries, 1989). Throughout the world, however, many studies have revealed that clearcut forests and those burned by wildfires differ markedly in post-disturbance biological legacies, vegetation structure, plant species composition, landscape patchiness and successional trajectory (McRae et al., 2001; Korpilahti and Kuuluvainen, 2002; Puettmann et al., 2008; Lindenmayer, 2009; Swanson et al., 2011). Such differences can be vital for sensitive biota (Hunter, 2007) and key ecosystem processes such as carbon storage (Keith et al., 2009).

In the tropics, some have argued that selective logging approximates the impacts of natural disturbances such as treefalls and windstorms (Hartshorn, 1989; Chazdon, 1998). Others have disputed this, arguing that logging only poorly mimics natural disturbance dynamics, facilitates exotic species invasions, and can promote major declines of disturbance-sensitive species (Saxon, 1990; Bowles et al., 1998; Zang and Ding, 2009). In many tropical landscapes, logging co-occurs with forest loss and fragmentation, hunting, fires, and other human disturbances. Synergisms among these disturbances can have severe impacts on some species (Laurance and Useche, 2009).

We argue that although the use of natural disturbance regimes to guide human-induced disturbances has considerable merit (Hunter, 2007), it also has at least six key limitations that resource managers must recognize. First, it can be difficult to quantify the most appropriate disturbance regime(s) for a given species, forest type or forest landscape because of the spatial and temporal variability in disturbance attributes, such as intensity, frequency and timing (Gill, 1975) and their relationships with other issues such as the ensembles of patch types and conditions that underpin the development of landscape mosaics (sensu Bennett et al., 2006). Second, the concept is both difficult to test and actually remains largely untested in most forest ecosystems. Third, some complex forest-ecosystem processes are extremely difficult to emulate (James and Norton, 2002). Fourth, natural disturbances sometimes induce non-linear or threshold changes in ecological processes, species interactions, and population sizes in which there is a sudden switch from one state to a markedly different one (Laurance et al., 2011; Lindenmayer et al., 2011b). Fifth, the needs of particular taxa and the conservation requirements for particular areas may not be met. Many landscapes have changed as a result of prior human disturbances such as vegetation clearance, and "natural" disturbance regimes may no longer be appropriate or achievable. Finally, human and natural disturbances may be spatially or temporally associated. Salvage logging after natural disturbance is one prominent example (Lindenmayer et al., 2008). The increased flammability of tropical forests and some moist temperate and boreal forest types following logging is another (e.g. Uhl and Kauffman, 1990; Lindenmayer et al., 2009, 2011a; Malhi et al., 2009).

\subsection{Carbon storage and sequestration are often confused}

Young forests typically grow faster than do old forests. This has sometimes been used to argue for the cutting of old-growth forests to create young, fast-growing stands or even-aged plantations. According to this argument, the carbon from old forests is then stored long-term in wood products like furniture, while carbon is rapidly sequestered into the newly created young forests.

However, such arguments confuse rates of carbon sequestration with carbon storage. Full carbon accounting is needed to quantify the carbon stored in young regenerating stands or plantations and in the old-growth forests they replace (Harmon et al., 1990; Ryan et al., 2010; Pan et al., 2011). It is also needed to account for carbon emissions from removal of the original forest cover, soil disturbance, and energy demands of the forest-conversion process (Hudiberg et al., 2009). For example, plantations of trees harvested on short rotations may actually contribute to net carbon output, adding to global carbon emissions rather than reducing them (Harmon et al., 1990; Murray et al., 2004). This is due primarily to the large carbon costs involved in establishing, felling, transporting, and re-planting tree plantations, as well as carbon lost from soil disturbance and post-harvesting fires (Schlesinger, 2000; Guo and Gifford, 2002).

Accurate carbon accounting also requires an accurate carbonsequestration baseline for a project site, against which all subsequent carbon calculations are measured. If baselines are established after native old-growth forest is cleared, plantations may appear to have a much higher net sequestration rate than they actually do. A classic example is clearing an old-growth forest to establish a fast-growing plantation, where the accounting begins when the plantation is established - such as was widely used with the 1990 baseline in the Kyoto Protocol (Watson et al., 2000).

In summary, while young forests generally grow and accumulate biomass faster than do old forests, this is not a scientifically valid basis for replacing old stands with young stands or tree plantations (Luyssaert et al., 2008; Ryan et al., 2010; Pan et al., 2011). Conversely, arguments for forest conversion need to be countered by calls for full carbon accounting to ensure forest managers do not confuse short-term rates of carbon sequestration with long-term carbon storage.

\section{Ecologically sustainable forest management}

Several studies have shown that unlogged "primary" forests have higher biodiversity values than do logged or regenerating forests (e.g. Gardner et al., 2009; Gibson et al., 2011) and that some species can be eliminated or extremely rare in forests that are logged (Laurance and Laurance, 1996; Lindenmayer et al., 1999; Peres, 2005). However, this does not mean that logged forests are without value for biodiversity (Chazdon et al., 2009; Gardner et al., 2009; Edwards et al., 2010), as human-disturbed forests are clearly superior environments for forest biodiversity than is no forest at all. Nevertheless, the way human-disturbed forests are managed can have a significant influence on other values, making it vital to develop management strategies that integrate timber production with biodiversity conservation, long-term carbon storage, and other key ecosystem processes as a fundamental part of ecologically sustainable forest management (Lindenmayer and Franklin, 2002). Indeed, ecologically sustainable forest management is critical for the $\sim 85 \%$ of the global forest estate that is neither under plantations nor large reserves (FAO, 2010). Balancing the environmental, economic, and social values of these multi-use forests is essential to generate economic benefits for governments, private landowners and trust managers, thereby helping to prevent conversion of millions of hectares of forest annually (FAO, 2010) to other uses such as tree plantations, agriculture and built environments, with corresponding losses of biodiversity and ecosystem services (Putz et al., 2008; Fayle et al., 2010; Smith et al., 2010).

Developing ecologically sustainable forest management practices is far from straight-forward because, as the issues briefly outlined above indicate, logging can affect key biodiversity, carbon 
and ecosystem-process values at a range of spatial and temporal scales. Hence, there is far more to ecologically sustainable forest management than, for example, simplistic statements of the percentage of a given natural forest area that is logged in any given year. This, in turn, indicates that a range of conservation and other forest-management strategies need to be implemented at a range of spatial scales - from individual trees to entire regions (reviewed by Lindenmayer and Franklin, 2002). These strategies include, among many others: (1) The protection of large ecological reserves (Peres, 2005). (2) The protection of key habitats within landscapes broadly designated for logging, including aquatic ecosystems and networks (such as rivers, streams, lakes and ponds), specialized habitats and localized biological hotspots (e.g. cliffs, caves and spawning areas), and rare habitats. (3) The establishment of landscape-level goals for retention, maintenance, or restoration of particular habitats or structures as well as limits to specific conditions (e.g. the amount of temperate dry forest landscapes subject to prescribed burning). (4) The selection of the spatial and temporal pattern for harvest units or other forest management units. (5) The careful design of roads to account for the potential impacts on critical habitats, ecological processes, and species (e.g. through indirect effects like increased human hunting pressure). (6) Structural retention of key components of the original stand at the time of logging (e.g. large trees [and associated recruit trees] and understory thickets) through retention harvesting in boreal and temperate forests (Puettmann et al., 2008) and Reduced Impact Logging in the tropics (Eltz et al., 2003; Putz et al., 2008). (7) Management of regenerating (secondary) stands to create specific structural conditions. (8) Long rotations or cutting cycles.

These strategies will often be a critical part of attempts to develop forest management plans and practices that are ecologically sustainable. However, their specific application - both singularly and in concert, will vary substantially between given areas of forest depending on context, physical and biological conditions, species assemblages, ecological processes, human developments (such as roads), the objectives of the landowner(s), and regulatory and social directives (Lindenmayer and Franklin, 2002).

\section{Concluding comments}

Out of a constellation of relevant issues in temperate and tropical forest management, we have highlighted five that have been hotly debated at times and which have particular relevance for biodiversity conservation. An appreciation of these issues by conservation biologists, forest managers and policy makers is important to help guide thinking about forest management practices and to guide them towards being truly ecologically sustainable.

\section{Acknowledgments}

C. Shepherd assisted with preparation of this paper. DBL thanks a number of colleagues for past work that has informed the perspectives outlined in this paper particularly Ross Cunningham, Jeff Wood, Jerry Franklin, and Gene Likens. Comments by two anonymous reviewers considerably improved an earlier version of this manuscript.

\section{References}

Angelstam, P., Majewski, P., Bondrup-Neilsen, S., 1995. West-East cooperation in Europe for sustainable boreal forests. Water Air Soil Poll 82, 3-11.

Asner, G.P., Broadbent, E.N., Oliveira, P., Keller, M., Knapp, D.E., Silva, J., 2006 Condition and fate of logged forests in the Brazilian Amazon. Proc. Natl. Acad. Sci. USA 103, 12947-12950.

Barlow, J., Mestre, L.A.M., Gardner, T.A., Peres, C.A., 2007. The value of primary, secondary and plantation forests for Amazonian birds. Biol. Conserv. 136, 212231.
Baum, J.K., Myers, R.A., 2004. Shifting baselines and the decline of pelagic sharks in the Gulf of Mexico. Ecol. Lett. 7, 135-145.

Bennett, A.F., Radford, J.Q., Haslem, A., 2006. Properties of land mosaics: Implications for nature conservation in agricultural landscapes. Biol. Conserv. 133, 250-264.

Bowles, I.A., Rice, R.E., Mittermeier, R.A., da Fonseca, G.A.B., 1998. Logging and tropical forest conservation. Science 280, 1899-1900.

Bunnell, F.L., Dunsworth, G.B. (Eds.), 2009. Forestry and Biodiversity: Learning How to Sustain Biodiversity in Managed Forests. UBC Press, Vancouver.

Carey, A.B., 2007. AIMing for Healthy Forests: Active, Intentional Management For Multiple values. USDA Forest Service Pacific Northwest Research Station, Olympia, Washington.

Chambers, J.Q., Higuchi, N., Schimel, J.P., 1998. Ancient trees in Amazonia. Nature 391, 135-136.

Chazdon, R.L., 1998. Tropical forests: log 'em or leave 'em? Science 281, 1295-1296.

Chazdon, R.L., Peres, C.A., Dent, D., Sheil, D., Lugo, A.E., Lamb, D., Stork, N.E., Miller, S.E., 2009. The potential for species conservation in tropical secondary forests. Conserv. Biol. 23, 1406-1417.

Cochrane, M.A., 2003. Fire science for rainforests. Nature 42, 913-919.

Cochrane, M.A., Laurance, W.F., 2008. Synergisms among fire, land use, and climate change in the Amazon. Ambio 37, 522-527.

Cocklin, C., Parker, S., Hay, J., 1992. Notes on cumulative environmental change I. Concepts and issues. J. Environ. Manage. 35, 31-49.

Corlett, R.T., 2007. The impact of hunting on the mammalian fauna of tropical Asian forests. Biotropica 39, 292-303.

Crome, F.H.J., More, L.A., Richards, G.C., 1992. A study of logging damage in upland rainforest in north Queensland. Forest Ecol. Manage. 49, 1-29.

Department of Primary Industries - New South Wales, 2011. Forest Glossary. Department of Primary Industries, New South Wales.

Department of Sustainability and Environment, VicForests, 2008. Joint Sustainable Harvest Level Statement. Department of Sustainability and Environment, Melbourne.

Edwards, D.P., Larsen, T.H., Docherty, T.D., Ansell, F.A., Hsu, W.W., Derhe, M.A., Hamer, K.C., Wilcove, D.S., 2010. Degraded lands worth protecting: the biological importance of Southeast Asia's repeatedly logged forests. Proc. Roy. Soc. Lond. B. 278, 82-90.

Eltz, T., Bruhl, C.A., Imiyabir, Z., Linsenmair, K.E., 2003. Nesting and nest trees of stingless bees (Apidae: Meliponini) in lowland dipterocarp forests in Sabah, Malaysia, with implications for forest management. Forest Ecol. Manage. 172, 301-313.

FAO, 2010. Global Forest Resources Assessment 2010: Main report. FAO, Rome.

Fayle, T.M., Turner, E.C., Snaddon, J.L., Chey, V.K., Chung, A.Y., Eggleton, P., Foster, W.A., 2010. Oil palm expansion into rain forest greatly reduces ant biodiversity in canopy, epiphytes and leaf-litter. Basic Appl. Ecol. 11, 337-345.

Felton, A., Wood, J., Felton, A.M., Lindenmayer, D.B., 2008. Bird community responses to reduced-impact logging in a certified forestry concession in lowland Bolivia. Biol. Conserv. 141, 545-555.

Fimbel, R.A., Grajal, A., Robinson, J.G. (Eds.), 2001. The Cutting Edge: Conserving Wildlife in Logged Tropical Forests. Columbia University Press, New York.

Franklin, J.F., Forman, R.T., 1987. Creating landscape patterns by forest cutting: ecological consequences and principles. Landscape Ecol. 1, 5-18.

Franklin, J.F., Lindenmayer, D.B., MacMahon, J.A., McKee, A., Magnuson, J., Perry, D.A., Waide, R., Foster, D.R., 2000. Threads of continuity. Conserv. Biol. Pract. 1, 8-16.

Frelich, L.E., 2005. Forest Dynamics and Disturbance Regimes. Studies from Temperate Evergreen-Deciduous Forests. Cambridge University Press, Cambridge, England.

Gardner, T.A., Barlow, J., Chazdon, R., Ewers, R.M., Harvey, C.A., Peres, C.A., Sodhi, N.S., 2009. Prospects for tropical forest biodiversity in a human-modified world. Ecol. Lett. 12, 561-582.

Gibson, L., Lee, T.M., Koh, L.P., Brook, B.W., Gardner, T.A., Barlow, J., Peres, C.A., Bradshaw, C.J.A., Laurance, W.F., Lovejoy, T.E., Sodhi, N.S., 2011. Primary forests are irreplaceable for sustaining tropical biodiversity. Nature 478, 378-381.

Gill, A.M., 1975. Fire and the Australian flora: a review. Austral. For. 38, 4-25.

Greiser Johns, A., 1997. Timber Production and Biodiversity Conservation in Tropical Forests. Cambridge University Press, Cambridge.

Grieser Johns, A., Grieser Johns, B., 1995. Tropical forest primates and logging: longterm coexistence? Oryx 29, 205-211.

Guo, L.B., Gifford, R.M., 2002. Soil carbon stocks and land use change: a meta analysis. Glob. Change Biol. 8, 345-360.

Gustafsson, L., Kouki, J., Sverdrup-Thygeson, A., 2010. Tree retention as a conservation measure in clearcut forests of northern Europe: a review of ecological consequences. Scand. J. Forest Res. 25, 295-308.

Gustavsson, E., Lennartsson, T., Emanuelsson, M., 2007. Land use more than 200 years ago explains current grassland plant diversity in a Swedish agricultural landscape. Biol. Conserv. 138, 47-59.

Halme, P., Toivanen, T., Honkanen, M., Kotiaho, J.S., Monkkonen, M., Timonen, J., 2010. Flawed meta-analysis of biodiversity effects of forest management. Conserv. Biol. 24, 1154-1156.

Harmon, M.E., Ferrell, W.K., Franklin, J.F., 1990. Effects of carbon storage on conversion of old-growth forest to young forests. Science 9, 699.

Hartshorn, G., 1989. Application of gap theory to tropical forest management of natural regeneration on strip clear cuts in the Peruvian Amazon. Ecology 70, 567-569.

Hudiburg, T., Law, B., Turner, D.P., Campbell, J., Donato, D., Duane, M., 2009. Carbon dynamics of Oregon and Northern California forests and potential land-based carbon storage. Ecol. Appl. 19, 163-180. 
Huggett, R., Cheeseman, J., 2002. Topography and the Environment. Prentice Hall, London.

Hunter, M.L., 1993. Natural fire regimes as spatial models for managing boreal forests. Biol. Conserv. 65, 115-120.

Hunter, M.L., 2007. Core principles for using natural disturbance regimes to inform landscape management. In: Lindenmayer, D.B., Hobbs, R.J. (Eds.), Managing and Designing Landscapes for Conservation: Moving from Perspectives to Principles. Blackwell Publishing, Oxford.

James, I.L., Norton, D.A., 2002. Helicopter-based natural forest management for New Zealand's Rimu (Dacrydium cupressinum, Podocarpaceae) forests. Forest Ecol. Manage. 155, 337-346.

Johnson, E.A., Miyanishi, K., 2008. Testing the assumptions of chronosequences in succession. Ecol. Lett. 11, 419-431.

Kavanagh, R.P., Bamkin, K.L., 1995. Distribution of nocturnal forest birds and mammals in relation to the logging mosaic in south-eastern New South Wales. Australia. Biol. Conserv. 71, 41-53.

Keith, H., Mackey, B.G., Lindenmayer, D.B., 2009. Re-evaluation of forest biomass carbon stocks and lessons from the world's most carbon-dense forests. Proc. Natl. Acad. Sci. USA 106, 11635-11640.

Kellas, J.D., Hateley, A.J.M., 1991. Management of dry sclerophyll forests in Victoria. I. The low elevation mixed forests. In: McKinnell, F.H., Fox, J.E.D. (Eds.), Forest Management in Australia. Surrey Beatty, Chipping Norton, pp. 142-162.

Korpilahti, E., Kuuluvainen, T., 2002. Disturbance dynamics in boreal forests: defining the ecological basis of restoration and management of biodiversity. Silva Fenn. 36, 1-447.

Laurance, W.F., 1991. Ecological correlates of extinction proneness in Australian tropical rain-forest mammals. Conserv. Biol. 5, 79-89.

Laurance, W.F., 2001. Tropical logging and human invasions. Conserv. Biol. 15, 4-5.

Laurance, W.F., Laurance, S.G., 1996. Responses of five arboreal marsupials to recent selective logging in tropical Australia. Biotropica 28, 310-322.

Laurance, W.F., Useche, D.C., 2009. Environmental synergisms and extinctions of tropical species. Conserv. Biol. 23, 1427-1437.

Laurance, W.F., Laurance, S.G., Ferreira, L.V., Rankin-de Merona, J., Gascon, C., Lovejoy, T.E., 1997. Biomass collapse in Amazonian forest fragments. Science 278, 1117-1118.

Laurance, W.F., Delamonica, P., Laurance, S.G., Vasconcelos, H.L., Lovejoy, T.E., 2000. Rainforest fragmentation kills big trees. Nature 404, 836.

Laurance, W.F., Nascimento, H.E.M., Laurance, S., Condit, R., D’Angelo, S., Andrade, A., 2004. Inferred longevity of Amazonian rainforest trees based on a long-term demographic study. Forest Ecol. Manag. 190, 131-143.

Laurance, W.F., Nascimento, H.E., Laurance, S.G., Andrade, A., Ewers, R.M., Harms, K.E., Luizao, R.C., Ribeiro, J.E., 2007. Habitat fragmentation, variable edge effects, and the landscape-divergence hypothesis. PLOS One 2, e1017, doi:1010.1371/ journal.pone.0001017.

Laurance, W.F., Dell, B., Turton, S.M., Lawes, M.J., Hutley, L.B., McCallum, H., Dale, P., Bird, M., Hardy, G., Prideaux, G., Gawne, B., McMahon, C.R., Yu, R., Hero, J.-M., Schwarzkopf, L., Setterfield, S.A., Krockenberger, A., Douglas, M., Silvester, E., Mahony, M., Vella, K., Saikia, U., Wahren, C.-H., Xu, Z., Smith, B., Cocklin, C. 2011. The ten Australian ecosystems most vulnerable to tipping points. Biol. Conserv. 144, 1472-1480.

Lindenmayer, D.B., 2009. Forest Pattern and Ecological Process: A Synthesis of 25 Years of Research. CSIRO Publishing, Melbourne.

Lindenmayer, D.B., Franklin, J.F., 2002. Conserving Forest Biodiversity: A Comprehensive Multiscaled Approach. Island Press, Washington DC.

Lindenmayer, D.B., Likens, G.E., 2010. Effective Ecological Monitoring. CSIRO Publishing and Earthscan, Melbourne and London.

Lindenmayer, D.B., Cunningham, R.B., McCarthy, M.A., 1999. The conservation of arboreal marsupials in the montane ash forests of the central highlands of Victoria, South-eastern Australia: VIII. Landscape analysis of the occurrence of arboreal marsupials. Biol. Conserv. 89, 83-92.

Lindenmayer, D.B., Burton, P.J., Franklin, J.F., 2008. Salvage Logging and Its Ecological Consequences. Island Press, Washington DC.

Lindenmayer, D.B., Hunter, M.L., Burton, P.J., Gibbons, P., 2009. Effects of logging on fire regimes in moist forests. Conserv. Lett. 2, 271-277.

Lindenmayer, D.B., Hobbs, R.J., Likens, G.E., Krebs, C., Banks, S., 2011a. Newly discovered landscape traps produce regime shifts in wet forests. Proc. Natl. Acad. Sci. USA 108, 15887-15891.

Lindenmayer, D.B., Wood, J., McBurney, L., Michael, D., Crane, M., MacGregor, C. Montague-Drake, R., Banks, S., Gibbons, P., 2011b. Cross-sectional versus longitudinal research: a case study of trees with hollows and marsupials in Australian forests. Ecol. Monogr. 81, 557-580.

Linder, P., Östlund, L., 1998. Structural changes in three mid-boreal Swedish forest landscapes, 1885-1996. Biol. Conserv. 85, 9-19.

Luyssaert, S., Detlef-Schulze, E., Borner, A., Knohl, A., Hessenmoller, D., Law, B.E., Ciais, P., Grace, J., 2008. Old-growth forests as global carbon sinks. Nature 455, 213-215.

Malhi, Y., Aragao, L.E., Galbraith, D., Huntingford, C., Fisher, R., Zelazowski, P., Sitch, S., McSweeney, C., Meir, P., 2009. Exploring the likelihood and mechanism of a climate-change-induced dieback of the Amazon rainforest. Proc. Natl. Acad. Sci. USA 106, 20610-20615.

McRae, D.J., Duchesne, L.C., Freedman, B., Lynham, T.J., Woodley, S., 2001. Comparisons between wildfire and forest harvesting and their implications in forest management. Environ. Rev. 9, 223-260.
Milly, P.C., Betancourt, J., Falkenmark, M., Hirsch, R.M., Kundzewicz, Z.W., Lettenmaier, D.P., Stouffer, R.J., 2008. Stationarity is dead: Whither water management? Science 319, 573-574.

Murray, B.C., McCarl, B.A., Lee, H.C., 2004. Estimating leakage from forest carbon sequestration programs. Land Econ. 80, 109-124.

National Association of Forest Industries, 1989. Wood production and the environment: working in harmony with nature. National Association of Forest Industries, Canberra.

Odion, D.C., Frost, E.J., Strittholt, J.R., Jiang, H., Dellasala, D.A., Moritz, M.A., 2004 Patterns of fire severity and forest conditions in the western Klamath Mountains, California. Conserv. Biol. 18, 927-936.

Paillet, Y., Berges, L., Hjalten, J., Odor, P., Avon, C., Bernhardt-Römermann, M., Bijlsma, R.J., De Bruyn, L., Fuhr, M., Grandin, U., Kanka, R., Lundin, L., Luque, S. Magura, T., Matesanz, S., Mészáros, I., Sebastià, M.-T., Schmidt, W., Standovár, T., Tóthmérész, B., Uotila, A., Valladares, F., Vellak, K., Virtanen, R., 2009. Biodiversity differences between managed and unmanaged forests: metaanalysis of species richness in Europe. Conserv. Biol. 24, 101-112.

Pan, Y., Birdsey, R.A., Fang, J., Houghton, R.A., Kauppi, P.E., Kurz, W.A., Phillips, O.L., Shvidenko, A., Lewis, S.L., Canadell, J.G., Ciais, P., Jackson, R.B., Pacala, S.W. McGuire, A.D., Piao, S., Rautianen, A., Sitch, S., Hayes, D., 2011. A large and persistent carbon sink in the world's forests. Science 333, 988-993.

Papworth, S., Rist, J., Coad, L., Milner-Gulland, E., 2009. Evidence for shifting baseline syndrome in conservation. Conserv. Lett. 2, 93-100.

Pauly, D., 1995. Anecdotes and the shifting baseline syndrome of fisheries. Trends Ecol. Evol. 10, 430.

Peres, C.A., 2005. Why we need mega-reserves in Amazonia. Conserv. Biol. 19, 728 733.

Pickett, S.T.A., 1989. Space-for-time substitution as an alternative to long-term studies. In: Likens, G.E. (Ed.), Longterm Studies in Ecology: Approaches and Alternatives. Springer-Verlag, New York, USA, pp. 110-135.

Puettmann, K.J., Coates, K.D., Messier, C., 2008. A Critique of Silviculture. Managing for Complexity. Island Press, Washington, DC.

Putz, F.E., Sist, P., Fredricksen, T., Dykstra, D., 2008. Reduced-impact logging: challenges and opportunities. Forest Ecol. Manag. 256, 1427-1433.

Redford, K.H., 1992. The empty forest. BioScience 42, 412-422.

Ritchie, E.G., Johnson, C.N., 2009. Predator interactions, mesopredator release and biodiversity conservation. Ecol. Lett. 12, 982-998.

Roccaforte, J.P., Fule, P.Z., Covington, W.W., 2010. Monitoring landscape-scale Ponderosa Pine restoration treatment implementation and effectiveness. Restor. Ecol. 18, 820-833.

Ryan, M.G., Harmon, M.E., Birdsey, R.A., Giardina, C.P., Heath, L.S., Houghton, R.A. Jackson, R.B., McKinley, D.C., Morrison, J.F., Murray, B.C., Pataki, D.E., Skog, K.E., 2010. A synthesis of the science on forests and carbon for U.S. forests. Issues Ecol. 13, 1-16.

Saxon, E.C., 1990. Disturbance regimes in north Queensland rainforests: a reevaluation of their relationship to species and diversity. Aust. J. Ecol. 15, 241 244.

Schlesinger, W.H., 2000. Carbon sequestration in soils: some cautions amidst optimism. Agr. Ecosyst. Environ. 82, 121-127.

Smith, P., Gregory, P.J., van Vuuren, D., Obersteiner, M., Havlik, P., Rounsevell, M., Woods, J., Stehfest, E., Bellarby, J., 2010. Competition for land. Philos. Trans. Roy. Soc. B. 365, 2941-2957.

Soulé, M.E., Noss, R.F., 1998. Rewilding and biodiversity: complementary goals for continental conservation. Wild Earth 8, 19-27.

Spies, T.A., Johnson, K.N., Burnett, K.M., Ohmann, J.L., McComb, B.C., Reeves, G.H., Bettinger, P., Kline, J.D., Garber-Yonts, B., 2007. Cumulative ecological and socioeconomic effects of forest policies in Coastal Oregon. Ecol. Appl. 17, 5-17.

Swanson, M.E., Franklin, J.F., Beschta, R.L., Crisafulli, C.M., DellaSala, D.A., Hutto, R.L Lindenmayer, D.B., Swanson, F.J., 2011. The forgotten stage of forest succession: early-successional ecosystems on forest sites. Front. Ecol. Environ. 9, 117-125

Thompson, J.R., Spies, T.A., Ganio, L.M., 2007. Reburn severity in managed and unmanaged vegetation in a large wildfire. Proc. Natl. Acad. Sci. USA 104, $10743-$ 10748.

Uhl, C., Kauffman, J.B., 1990. Deforestation, fire susceptibility, and potential tree responses to fire in the Eastern Amazon. Ecology 71, 437-449.

Victorian Association of Forest Industries, 2011. Forestry in Victoria: Key Issues and Facts. Victorian Association of Forest Industries, Melbourne, Victoria.

Watson, R.T., Noble, I.R., Bolin, B., Ravindranath, N.H., Verardo, D.J., Dokken, D.J (Eds.), 2000. Land Use, Land-Use Change, and Forestry: A Special Report of the Intergovernmental Panel on Climate Change. Cambridge University Press, Cambridge.

World Growth, 2010. Caught Red-handed: The Myths, Exaggerations and Distortions of Greenpeace, Friends of the Earth and Rainforest Action Network. World Growth International, Washington, DC.

Yabe, T., Rittl, C.E., Higuchi, N., 1998. Especies de mamiferos registradas por camaras fotograficas automaticas na Estação Experimental de Silvicultura Tropical do Instituto Nacional de Pesquisas da Amazonia-EEST-INPA, Amazonia Central. In: Higuchi, N., Campos, M., Sampaio, P., dos Santos, J. (Eds.), Pesquisas florestais para a conservação da floresta e rehabilitação de areas degradadas da Amazonia. INPA, Manaus, Brazil, pp. 93-107.

Yaffee, S.L., 1994. The Wisdom of the Spotted Owl. Policy Lessons for a New Century Island Press, Washington, DC.

Zang, R., Ding, Y., 2009. Forest recovery on abandoned logging roads in a tropical montane rain forest of Hainan Island. Acta Ecologica 35, 462-470. 